Article

\title{
Contribution of GIS and Geochemical Proxies to Improving Habitat Identification and Delimitation for the Natura 2000 Network: The Case of Coastal Lagoons in Galicia (NW Iberian Peninsula)
}

\author{
Alejandro Gómez-Pazo ${ }^{1,2}$, Augusto Pérez-Alberti ${ }^{2,3}$, Pedro Fraga-Santiago ${ }^{2}$, \\ Martin Souto-Souto ${ }^{4}$ and X. L. Otero ${ }^{2,3,5, *}$ \\ 1 Departamento de Xeografía, Facultade de Xeografía e Historia, Universidade de Santiago de Compostela, \\ 15782 Santiago de Compostela, Spain; a.gomez@usc.es \\ 2 CRETUS Institute, Universidade de Santiago de Compostela, 15782 Santiago de Compostela, Spain; \\ augusto.perez@usc.es (A.P.-A.); pedro.fraga@rai.usc.es (P.F.-S.) \\ 3 Departamento de Edafoloxía e Química Agrícola, Facultade de Bioloxía, \\ Universidade de Santiago de Compostela, Campus Vida, 15782 Santiago de Compostela, Spain \\ 4 Centro de Investigação em Biodiversidade e Recursos Genéticos, CIBIO, InBIO Laboratório Associado, \\ Pólo dos Açores \& Faculdade de Ciências e Tecnologia da, Universidade dos Açores, \\ 9500-321 Ponta Delgada, Portugal; martin.s.souto@uac.pt \\ 5 REBUSC, Rede de Estacións Biolóxicas da USC, Casa do Hórreo, rúa da Ribeira, 1-4, \\ 15590 A Graña-Ferrol, Spain \\ * Correspondence: xl.otero@usc.es; Tel.: +34-881-813-300
}

Received: 4 December 2020; Accepted: 17 December 2020; Published: 18 December 2020

\begin{abstract}
The Natura 2000 network is an ambitious European project aimed at nature conservation. Nevertheless, the identification and delimitation of habitats is a complex task and simultaneously essential for correct ecosystem management. In this study we compared the current habitat delimitation and designation and the results produced by Geographic Information Systems (GIS) and geochemical proxies for the categorization of four coastal lakes in Galicia (NW Iberian Peninsula). The findings reveal important errors in the delimitation/designation. The first error is the designation of all four lakes as Coastal lagoons (habitat 1150), when geochemical data indicate that two of these lakes were always freshwater lakes and should consequently be classified as Natural eutrophic lakes (habitat 3150). Another error is of conceptual origin, because the lakes comprise a unique functional system composing of different environmental units (e.g., open water or aquatic vegetation). Subdivision into different habitats is therefore meaningless for units of negligible surface area. In addition, the designation of some habitats is very dubious according to the available data. Finally, notable changes in relation to the temporal changes of wetlands were observed. Thus, the area occupied by aquatic macrophytes increased greatly at the expense of open waters, and the increase was also reflected in the alluvial forest. This last finding indicates the importance of updating the state of Natura 2000 network in Galicia to improve habitat management.
\end{abstract}

Keywords: Habitats Directive; coastal lagoon; coastal lake; Natura 2000 network; habitats

\section{Introduction}

Wetland ecosystems are essential for biodiversity conservation as they are actively involved in improving water quality and nutrient cycling, and also function as atmospheric $\mathrm{CO}_{2}$ sinks [1-4]. In addition, these areas are very fragile and vulnerable to disturbance caused by human activity $[5,6]$. Large areas of European wetlands have been lost since the start of the 20th century and the remaining 
wetland habitats have been greatly altered $[7,8]$. In response to this situation, various different initiatives and international conventions were proposed in the middle of the 20th century with the aim of promoting the study and protection of these areas (e.g., International Waterfowl and Wetlands Research Bureau (IWRB) and the Ramsar Convention).

In 1992, the European Union approved Council Directive 92/43/EEC (referred to here-after as the Habitats Directive) on the conservation of natural habitats and of wild fauna and flora. This Directive established a network of Special Areas of Conservation to protect habitats considered to be of community importance (Annex I lists 233 natural habitats in Europe) and also wild animal and plant species that should be protected (about 900 species, Annex II). These habitats and species formed the basis for the creation of a network of special areas of conservation, called Natura 2000 [9]. The aim of the Natura 2000 network is to ensure the long-term survival of Europe's most valuable and threatened species and habitats, listed in both the Birds Directive (Council Directive 79/409/EEC, 1979) and the Habitats Directive. Member states are obliged to include in the Natura 2000 network all the natural spaces in their territory that include habitats and species that appear in Annex I and II, especially those considered priority spaces. Each Member State is also obliged to maintain and restore, with favorable conservation status, natural habitats, and species of wild fauna and flora of community interest covered in the Habitats Directive [9].

The Natura 2000 network is one of the most ambitious legislative instruments in the field of nature conservation worldwide. However, various problems hamper the effective application of the project. One of the main problems is related to the complexity of some articles (e.g., Art. 6) or ambiguities in the definition of multiple habitats, which has forced the European Commission to elaborate diverse manuals ad hoc, as [10]. Thus, to fully achieve the basic goals established in the Habitats Directive, it is essential to understand the processes and the nature of the components that define each habitat (e.g., drainage network and water composition). This is the only way of correctly designating and delimiting habitats. Much of this information was either not available or was not used when the Natura 2000 network was designed. Delimitation of each habitat is complicated by the method used, as well as by the fact that many protected areas undergo substantial temporal changes in relation to climate conditions and land use by local populations. This obliged the Member States to revise their status within the Natura 2000 network, as established in the Habitats Directive.

Galicia has more than $2100 \mathrm{~km}$ of coastline [11], and one of the most complex littoral zones in the Iberian Peninsula [12]. Coastal lakes represent one of the most unusual environments in the region. Despite their small size, some coastal wetlands appear among the priority habitats of Annex I and are thus included in the Spanish Natura 2000 network. As it can be difficult to establish boundaries between habitats that appear as a continuum $[13,14]$, in this study, we carried out a comparative analysis of the delimitation and designation of habitats that appear in the plan developed by the Xunta de Galicia (Government of the Autonomous Community of Galicia) for the implementation of the Natura 2000 network, i.e., the Plan Director de la Red Natura 2000 de Galicia (PDRN) (Decree 37/2014, Xunta de Galicia) for four lakes in the region. The information is included in the official cartography of the Xunta de Galicia, which is based on the data included in Annex I of the PDRN.

The main objectives of the present study were: (1) to rethink the designation of the Galician coastal lakes exclusively to the Coastal lagoon habitat; (2) to establish the boundaries of each lake by applying Geographic Information System (GIS) techniques and Light Detection and Ranging (LiDAR) data and geomorphological parameters; (3) to analyze the temporal dynamics in the coastal lakes through remote sensing techniques; and (4) to evaluate the excessive fragmentation of these lakes in habitats with questionable presence or limited representation. For this purpose, we used the information provided by aerial images, orthophotographs and LiDAR data (available from the Spanish National Geographic Institute [IGN]) and geochemical analysis of water and substrate composition in several field surveys. This study tries to explain the need to improve the mechanism to the conservation of nature, the aim of Nature 2000 network. 


\section{Materials and Methods}

\subsection{Study Area}

Galicia (NW Iberian Peninsula) has numerous coastal lakes of various sizes, forms, and hydrodynamics (see, for example: [15-18]). This study focuses on four coastal lakes (Figure 1) with different morphological and hydrodynamics characteristics. The four lakes (Louro, Xuño, Vixán, and Bodeira) are located in the Atlantic coastal region of Galicia. The region has a maritime climate. The annual average temperature is $14.6-16.2^{\circ} \mathrm{C}$, and average rainfall ranges from 1211 to 1828 $\mathrm{mm} /$ year [19]. However, most (70\%) of the precipitation is concentrated in the period between October and March, generating an intense drought period in the summer that determines the water availability in these lacustrine areas [19].
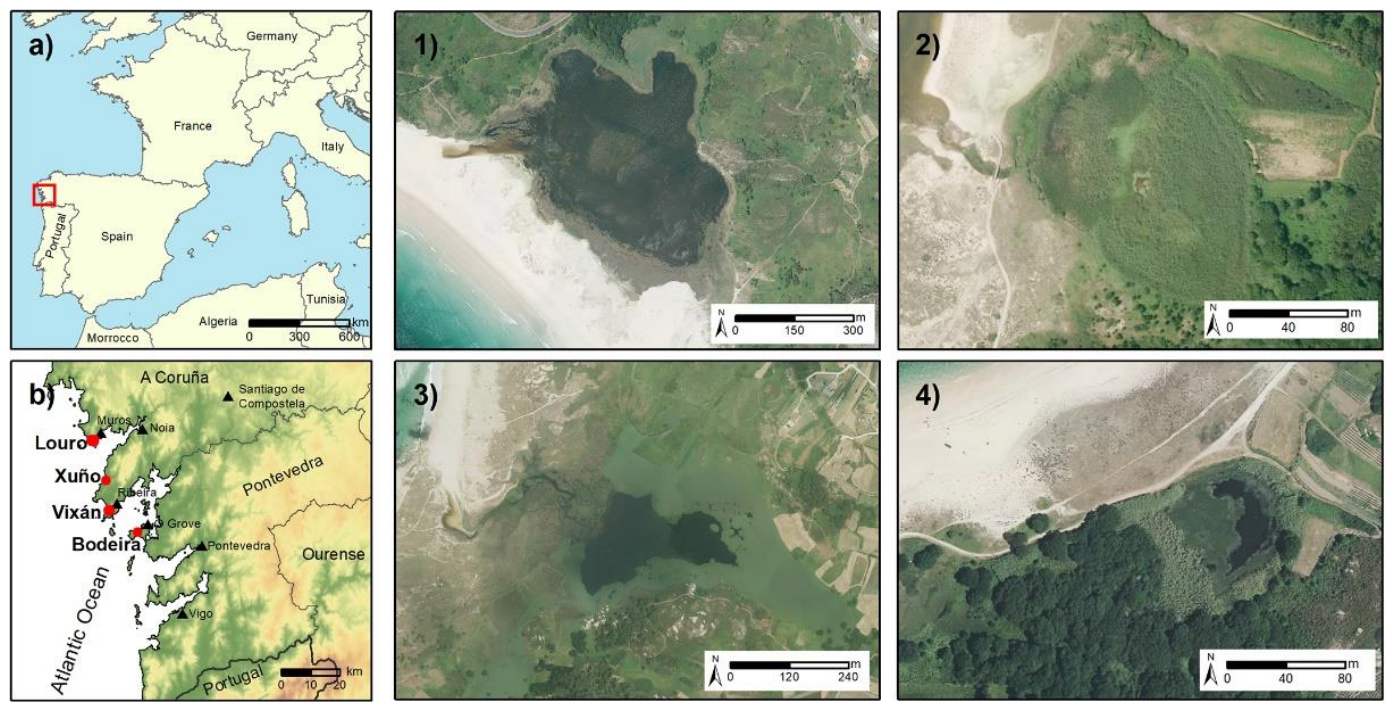

Figure 1. (a,b) represents the study areas in continental and regional level, respectively. In (b) appear the study areas represented in this figure with red dots, and the black triangles represent the main cities/villages in this area. Numbers 1 to 4 represent the analysis zones using an ortophotography of PNOA (Plan Nacional de Ortofotografía Aérea) captured in 2017 [20] and have the following sequence (1) Louro, (2) Xuño, (3) Vixán, and (4) Bodeira.

The Louro lake $\left(42^{\circ} 45^{\prime} 23^{\prime \prime} \mathrm{N}, 09^{\circ} 5^{\prime} 36^{\prime \prime} \mathrm{W}\right)$, which has an approximate surface area of 30 ha, is associated with a sedimentary complex with a beach and a large, well-developed dune system that partially closes the area connecting the lake and the sea (Figure 1(a1), i.e., a temporary channel at the NW edge [18].

The Vixán lake $\left(42^{\circ} 32^{\prime} 28^{\prime \prime} \mathrm{N}, 09^{\circ} 01^{\prime} 32^{\prime \prime} \mathrm{W}\right)$, which has an approximate surface area of 15 ha, forms part of the Natural Park Complexo dunar de Corrubedo e lagoas de Carregal e Vixán (Figure 1(b3). This lake is enclosed by a well-developed dune system and its connection to the sea is almost nil [15], partly due to the long distance $(\sim 300 \mathrm{~m})$ to the coastline.

The Xuño $\left(42^{\circ} 38^{\prime} 00^{\prime \prime} \mathrm{N}, 09^{\circ} 2^{\prime} 19^{\prime \prime} \mathrm{W}\right.$, Figure $\left.1(\mathrm{a} 2)\right)$ and Bodeira $\left(42^{\circ} 28^{\prime} 29^{\prime \prime} \mathrm{N}, 08^{\circ} 54^{\prime} 22^{\prime \prime} \mathrm{W}\right.$, Figure 1(b4)) lakes are both small ( $>3 \mathrm{ha}$ ) and located at the back of dune systems. In contrast to the other lakes, these lakes are located at a higher elevation ( $\sim 4-5$ m.a.s.l). The Bodeira lake lacks a connecting channel to the sea, while the Xuño lake the existing channel acts exclusively as an overflow channel during periods of heavy rainfall.

\subsection{Methodology}

Delimitation of the different environments in each lake was carried out using different proxies. Aerial images and Digital Elevation Models (DEMs) were used to characterize the sectors and to check 
the relationship with the nearby marine zone. In addition, water and sediment analyses were carried to determine various parameters.

\subsubsection{Delimitation of Temporal Changes in Coastal Lakes}

The lake systems were delimited using ArcGIS 10.5 (license USC), as follow:

1. A high resolution (1 m) Digital Surface Model (DSM) of the lake basin was generated using the most recent LiDAR data (from 2015 [20]).

2. The terrain ruggedness was determined using the Riley formulation [21]. This parameter was then used in the delimitation by considering the mean Topographic Ruggedness Index (TRI) as threshold.

3. The surface area was corrected by analysis of aerial images to adapt the lake space to the characteristics of each zone in 2017.

4. Remote sensing techniques were used to analyze the characteristics of the areas, such as the tone or the element size, for final delimitation of the spaces.

\subsubsection{Geochemical Analysis of Water and Sediments}

Lake water and sediments were sampled in different seasons during the period 2009-2011. Water samples were collected in Teflon jars previously treated with $\mathrm{HCl}(5 \%)$ and rinsed several times with Milli-Q water. Redox potential (Eh), $\mathrm{pH}$ and electrical conductivity (EC) were determined in situ with a multiparameter probe (Hanna Instruments, Ann Arbor, MI, USA). Salinity was determined with a Hanna refractometer. In the laboratory, the samples were filtered ( 0.45 microns). Nutrient concentrations $\left(\mathrm{NH}_{4}{ }^{+}, \mathrm{NO}_{3}{ }^{-}\right.$, and $\left.\mathrm{PO}_{4}{ }^{3+}\right)$ were determined by ion chromatography using a Dionex 4500i system (Dionex Inc., Sunnyvale, CA, USA). DBO5 was determined by incubation in an OxiTop Box (WTW at $20^{\circ} \mathrm{C}$ ).

Sediment samples were obtained from the center of each lake with PVC tubes of length $150 \mathrm{~cm}$ and inner diameter $80 \mathrm{~mm}$. In the laboratory, sediment samples were cut into 3 to $5 \mathrm{~cm}$ thick segments. The sediment samples were used to determine the influence (both present and past) of seawater in each lake, using the concentration of pyrite (S pyrite) in sediments relative to organic $\mathrm{C}$ content as a proxy measure [22]. The organic C/pyritic $S$ ratio is a proxy that distinguishes anoxic freshwater sediments (with low concentrations of pyrite, $\mathrm{FeS}_{2}$ ) from anoxic marine sediments (with high pyrite contents) [22-24]. The total organic C (TOC) content was determined in ground samples in a Leco TruSpec CHN analyzer (after removal of carbonates with $1 \mathrm{M} \mathrm{HCl}$ ), and the total $\mathrm{S}$ (TS) content was determined in a Leco SC144DR /C element analyzer. Fe oxyhydroxides and Fe pyrite $\left(\mathrm{FeS}_{2}\right)$ were determined by sequential Fe extraction (for more details see $[25,26]$ ). The pyritic $S$ content was determined stoichiometrically from the pyritic Fe content.

\section{Results and Discussion}

\subsection{Errors in Designation of Habitats in Annex I of the Habitats Directive}

The Habitats Directive obliges EU member states to designate special areas of conservation for habitats and species considered to be of community interest, in a network known as Natura 2000. The Nature 2000 network affects 30\% of the Spanish territory and the country has the largest area of land included in the network in the EU. Although this is very positive from an environmental point of view, it has led to difficulties in the execution of development plans in rural areas, particularly in the implementation of projects (e.g., wind parks and fish farms) where the location affects a Nature 2000 network space. The absence of clear guidelines for the correct, standardized interpretation of habitats included in Annex I has generated confusion and errors during the identification of areas that should be protected $[27,28]$. 
In Galicia, several areas degraded by anthropogenic activities were designated priority habitats. For instance, different Sphagnum acid bogs (habitat 7150) were located in a zone dominated by rocky outcrops or forest areas strongly affected by anthropogenic activities during a period of more than 30 years [29]. Likewise, the main Galician dune systems [30], which are often characterized by sediments with more than $10 \%$ of $\mathrm{CaCO}_{3}$, were designated as Atlantic decalcified fixed dunes (Calluno-Ulicetea) (priority habitat 2150) [31].

The coastal lakes, i.e., the focus of this study, represent another example of incorrect habitat designation, as all were identified as Coastal lagoons (priority habitat 1150). This applies to the Xuño and Bodeira lakes, but probably also applies to other coastal lakes in Galicia (e.g., Doniños), which do not fit within this habitat category in relation to the water composition, contrary to the definition given in the manuals published in the last few decades (e.g., [30]).

A significant weakness that appeared at the outset of the establishment of the Natura 2000 network was the lack of standardized criteria for interpreting the habitats and the inadequate scientific-technique knowledge of the work teams involved $[28,32,33]$. This weakness is, to a large extent, responsible for the problems identified in the present study.

\subsection{Official Cartography: Errors and Inconsistences in Habitat Delimitation and Designation}

The analysis conducted in the present study revealed that the delimitation and designation of habitats do not respond to clear, standardized criteria, leading to multiple inconsistences that preclude comparative studies between different Natura 2000 areas with similar characteristics.

One of the most common errors observed in this project was the excessive division of natural spaces into numerous habitats not related to the overall ecosystem functionality. In addition, incompatible habitats sometimes appear in the same space. Table 1 shows the main habitats designated as coastal lagoons, considered by official sources as only including bodies of water.

Table 1. Main, associated, and secondary habitats in the official cartography assigned to the studied lakes. The habitats that are not marked as relevant for the conservation in the official cartography were discarded. Source: Xunta de Galicia (C).

\begin{tabular}{cc}
\hline Code & Definition \\
\hline 1150 & Coastal lagoons \\
7210 & Calcareous fens with Cladium mariscus and species of the Caricion davallianae \\
2130 & Fixed coastal dunes with herbaceous vegetation (grey dunes) \\
2150 & Atlantic decalcified fixed dunes (Calluno-Ulicetea) \\
3150 & Natural eutrophic lake with Magnopotamion or Hydrocharition-type vegetation \\
5230 & Arborescent matorral with Laurus nobilis \\
6220 & Pseudo-steppe with grasses and annuals of the Thero-Brachypodietea \\
$91 \mathrm{E} 0$ & Alluvial forests with Alnus glutinosa and Fraxinus excelsior \\
\hline
\end{tabular}

In this study, we assumed that lake systems are complex habitats that include different environments and plant formations such as reed beds (communities of Phragmites australis), rushes (formation dominated by Juncus spp.) and aquatic vegetation (e.g., Ruppietea maritimae, Potametea, Zosteretea, and Charetea). The coexistence of several formations in the same habitat is explained in the description of coastal lagoons [9], which include salt marshes as part of these complexes.

Following on from this general framework for defining habitats in each lake in relation to the official cartography, we conducted an in-depth analysis of each sector in function of the composition of the water and sediments, as done for the delimitation. 


\subsection{Water and Sediment Composition}

\subsubsection{Water Composition and Quality}

The main physiochemical characteristics of the water in the four lakes are shown in Table 2. The water in the Louro and Vixán lakes is characterized by alkaline $\mathrm{pH}(\mathrm{pH} 8-9)$ and an elevated ionic concentration (EC mean values: $10-23 \mathrm{dS} \mathrm{m}^{-1}$ ). These results demonstrate the marine influence in both lake systems, which coincides with the definition of Coastal lagoons (habitat 1150): "Lagoons are expanses of shallow coastal salt water, of varying salinity and water volume, wholly or partially separated from the sea by sand banks or shingle, or, less frequently, by rocks. Salinity may vary from brackish water to hyper salinity depending on rainfall, evaporation and through the addition of fresh seawater from storms, temporary flooding of the sea in winter or tidal exchange... " [9].

Table 2. Water and sediments physicochemical properties and composition, na: not analyzed. $\mathrm{n}$ : number of samples.

\begin{tabular}{|c|c|c|c|c|c|c|c|}
\hline Site & $\mathrm{pH}$ & EC & DBO5 & $\mathrm{NH}_{4}{ }^{+}$ & $\mathrm{NO}_{2}{ }^{-}$ & $\mathrm{NO}_{3}{ }^{-}$ & $\mathrm{PO}_{4}{ }^{3-}$ \\
\hline \multicolumn{8}{|c|}{ Water } \\
\hline & & $\mathrm{dS} \mathrm{cm}^{-1}$ & & & $\mathrm{mg} \mathrm{L}^{-1}$ & & \\
\hline Louro $(\mathrm{n}=15)$ & $8.3 \pm 0.8$ & $23.3 \pm 10$ & $29 \pm 27$ & $0.30 \pm 0.22$ & $0.08 \pm 0.04$ & $2.19 \pm 1.24$ & $0.10 \pm 0.06$ \\
\hline Vixán $(\mathrm{n}=18)$ & $8.2 \pm 0.9$ & $10.1 \pm 0.7$ & $10 \pm 9.4$ & $0.09 \pm 0.04$ & $25.7 \pm 37.4$ & $2.34 \pm 1.37$ & $0.18 \pm 0.23$ \\
\hline Xuño $(\mathrm{n}=18)$ & $6.6 \pm 0.3$ & $0.46 \pm 0.2$ & $6.2 \pm 6.1$ & $0.08 \pm 0.10$ & $0.03 \pm 0.02$ & $1.96 \pm 2.23$ & $0.10 \pm 0.20$ \\
\hline Bodeira $(n=12)$ & $7.2 \pm 0.2$ & $0.41 \pm 0.1$ & $9.1 \pm 11$ & $0.08 \pm 0.12$ & $0.08 \pm 0.07$ & $23.5 \pm 42.9$ & $0.13 \pm 0.13$ \\
\hline \multicolumn{8}{|c|}{ Sediment } \\
\hline & $\mathrm{pH}$ & $\mathrm{EC}$ & Eh & \multirow{2}{*}{\multicolumn{2}{|c|}{ TOC }} & \multirow{2}{*}{\multicolumn{2}{|c|}{$\begin{array}{l}\text { Fe oxyhyd. } \quad \text { Fe pyrite } \\
\mu_{\mathrm{mol} \mathrm{g}}^{-1}\end{array}$}} \\
\hline & & $\mathrm{d} S \mathrm{~cm}^{-1}$ & $\mathrm{mV}$ & & & & \\
\hline Louro $(\mathrm{cm})$ & $(\mathrm{n}=2)$ & $(n=2)$ & $(\mathrm{n}=2)$ & $(\mathrm{n}=4)$ & $(\mathrm{n}=4)$ & $(\mathrm{n}=4)$ & $(\mathrm{n}=4)$ \\
\hline 0-15 & 6.8 & 24.1 & 124 & $8.6 \pm 1.8$ & $2.0 \pm 0.2$ & $37.0 \pm 15$ & $367 \pm 126$ \\
\hline $40-60$ & 6.9 & 20.1 & 110 & $4.2 \pm 0.7$ & $1.2 \pm 0.1$ & $11.9 \pm 5.8$ & $197 \pm 13$ \\
\hline Vixán $(\mathrm{cm})$ & $(\mathrm{n}=1)$ & $(\mathrm{n}=1)$ & $(\mathrm{n}=3)$ & $(\mathrm{n}=4)$ & $(\mathrm{n}=4)$ & $(\mathrm{n}=4)$ & $(\mathrm{n}=4)$ \\
\hline $0-15$ & 7.8 & 14 & $-78 \pm 9$ & $8.7 \pm 2.6$ & $0.91 \pm 0.4$ & $22.5 \pm 1.9$ & $131 \pm 55$ \\
\hline $40-60$ & 7.3 & & $-150 \pm 25$ & $1.6 \pm 0.3$ & $0.20 \pm 0.3$ & $23.0 \pm 7.0$ & $73.9 \pm 3.9$ \\
\hline 90-110 & na & 10.8 & na & $4.2 \pm 0.8$ & $0.92 \pm 0.1$ & na & na \\
\hline Xuño (cm) & $(\mathrm{n}=1)$ & $(\mathrm{n}=1)$ & $(\mathrm{n}=1)$ & $(\mathrm{n}=4)$ & $(\mathrm{n}=4)$ & $(\mathrm{n}=4)$ & $(\mathrm{n}=4)$ \\
\hline $0-15$ & 6.9 & -60 & 0.56 & $11.5 \pm 0.6$ & $0.26 \pm 0.16$ & $187 \pm 39$ & $0.24 \pm 0.17$ \\
\hline $40-60$ & 6.4 & -45 & na & $0.22 \pm 0.11$ & $0.02 \pm 0.02$ & $2.85 \pm 0.01$ & $0.05 \pm 0.01$ \\
\hline 90-110 & 6.5 & -12 & na & $1.76 \pm 0.06$ & $0.61 \pm 0.04$ & $1.04 \pm 1.52$ & $1.38 \pm 1.32$ \\
\hline Bodeira $(\mathrm{cm})$ & $(\mathrm{n}=1)$ & $(\mathrm{n}=1)$ & $(\mathrm{n}=1)$ & $(\mathrm{n}=4)$ & $(\mathrm{n}=4)$ & $(\mathrm{n}=4)$ & $(\mathrm{n}=4)$ \\
\hline $0-15$ & 6.1 & 70 & 0.76 & $24.6 \pm 4.6$ & $0.72 \pm 0.32$ & $89.1 \pm 18$ & $0.04 \pm 0.03$ \\
\hline $40-60$ & na & na & na & $5.30 \pm 1.40$ & $0.09 \pm 0.04$ & $63.4 \pm 15$ & $2.54 \pm 1.73$ \\
\hline 90-110 & 7 & -120 & na & $1.61 \pm 0.62$ & $0.45 \pm 0.02$ & $188 \pm 16$ & $2.99 \pm 1.78$ \\
\hline
\end{tabular}

By contrast, the water in the Xuño and Bodeira lakes was characterized by slightly acidic to neutral $\mathrm{pH}$ (6.6-7.2) and a low EC (>1 dS m $\left.{ }^{-1}\right)$, which indicate the strictly continental origin of these waters. The ionic concentration only increases during the winter periods as consequence of the deposition of marine spray [34]. Consequently, these lakes do not have the basic conditions established in the definition of coastal lagoons, and they should be assigned to the category Natural eutrophic lakes with Magnopotamion or Hydrocharition (habitat 3150).

In both types of coastal lakes, the water volume varied widely, with particularly large reductions at the end of summer or start of autumn, coinciding with the periods of highest drought (see below). The reduction in the volume of water in the lakes leads to a reduction in quality, due to increased concentrations of nitrogenated forms (nitrate and ammonium), phosphates, and DBO5 (Table 2), and thus to an increase in fish mortality events (e.g., Vixán lake, [34]). The toxic metal contents were very low in all the lakes under study (data not shown) [34]. 


\subsubsection{Sedimentary Composition}

The lake sediments were characterized by a predominance of the sand fraction ( $>75 \%$ in general terms: data not shown, [34]) and low contents of inorganic colloids such as Fe oxyhydroxides (Table 2). The organic content $C$ was very high in the superficial part of the lake sediments $(0-15 \mathrm{~cm})$, with mean values ranging between $8.6 \%$ in Louro and $24.6 \%$ in Bodeira. These values decreased with depth, but with alternating organic C-rich and -poor layers (Table 2; see also [18]). The $\mathrm{pH}$ was close to neutral, and the redox conditions were anoxic (Eh $<200 \mathrm{mV}$; [35]) in all cores (Table 2). The TS content was correlated with the TOC at depth (correlation TOC/TS, $\mathrm{rs}=0.739, p<0.001, \mathrm{n}=41$ ), indicating that most of the TS is organic S. Moreover, the relationship between TOC and pyrite S (Figure 2) revealed a clear difference between the Xuño and Bodeira lakes and the Louro and Vixán lakes. For the first pair, the superficial and deep samples always had freshwater characteristics, while the sediment samples from the second pair were more characteristic of marine environments. These results are consistent with the water composition, demonstrating that the Xuño and Bodeira lakes were never salt lagoons.

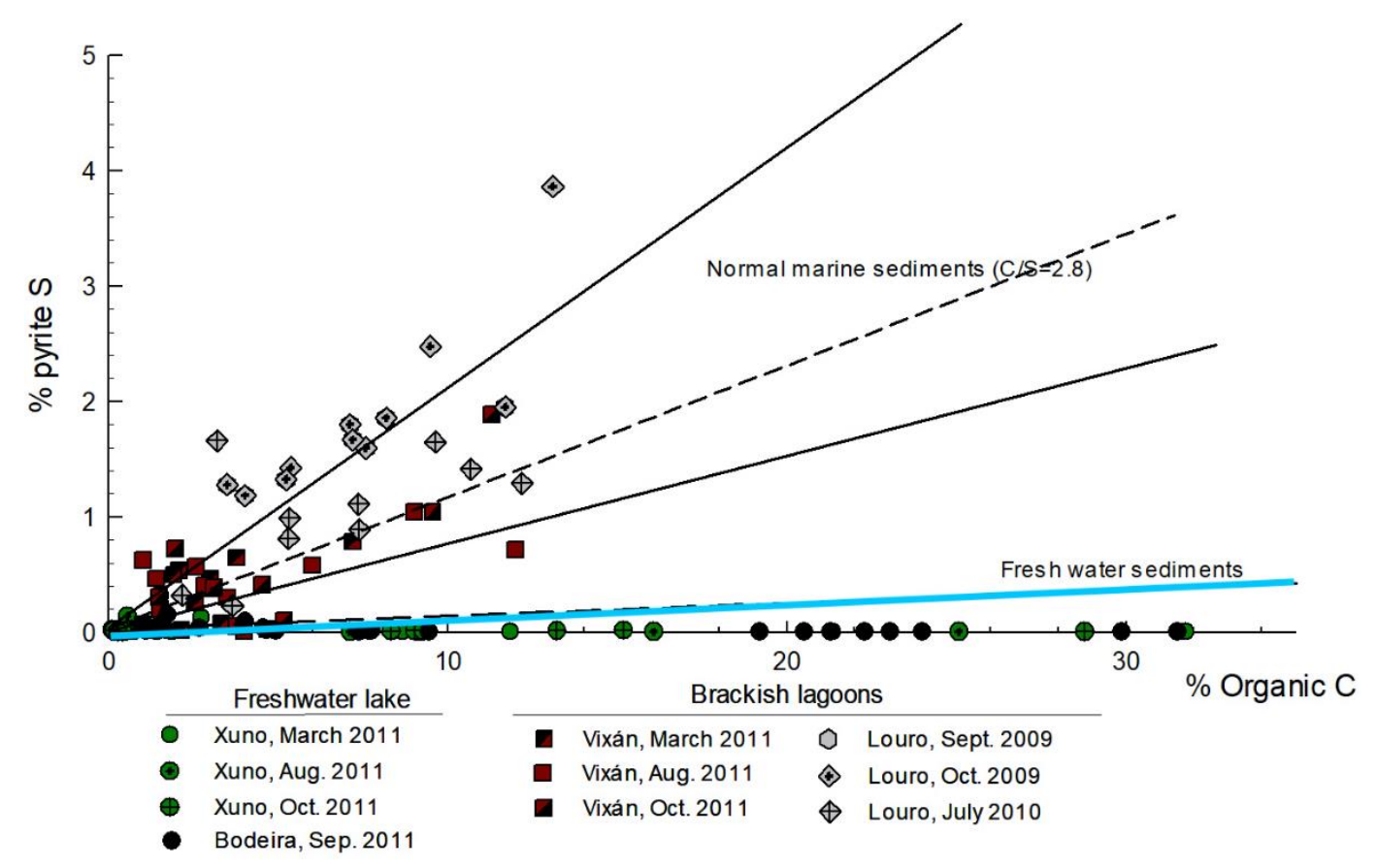

Figure 2. Organic carbon vs pyrite $\mathrm{S}$ in lake sediments. Black solid lines represent the typical relation for marine sediments $(C / S=2.8 \pm 1.5 ;[23,36])$, while the blue solid line represent the same relation for freshwater environments with a reduce sulphate concentration [22]. For each location, the graph shows the results in surficial and deep samples (up to 100-110 cm in depth). The high relation C/S in all samples indicate that Xuño and Bodeira were always freshwater lakes.

\subsection{Delimitation of Coastal Lakes}

The terrain ruggedness determined by the Riley formulation [21] enabled delimitation of the maximum extension of the lake basin. The surface areas were around $5 \%$ larger than those established with the 2017 orthophotograph (Figures 3, 4, 7, and 8). This finding indicates partial occupation of the actual surface area of the lakes, particularly by agricultural activities. The sectors present in each lake were estimated independently, and their characteristics are included in Table 3. 
Table 3. Estimated surface in each sector follow our delimitation for the case of the second and third column and employed the surface values included in Annex I of PDRN over the interest zone for this study in the columns defined as "Area defined by autonomous government". (Source: Xunta de Galicia (C).

\begin{tabular}{ccccc}
\hline \multirow{2}{*}{ Zone } & $\begin{array}{c}\text { Lagoon/Lake Area } \\
\text { (ha) }\end{array}$ & $\begin{array}{c}\text { Free Water Surface } \\
\text { (ha) }\end{array}$ & \multicolumn{2}{c}{$\begin{array}{c}\text { Area Defined by Autonomous } \\
\text { Government }\end{array}$} \\
\cline { 4 - 5 } & & & $\begin{array}{c}\text { Coastal Lagoon } \\
\text { (ha) }\end{array}$ & $\begin{array}{c}\text { Natural Eutrophic } \\
\text { Lake (ha) }\end{array}$ \\
\hline Louro & 33.6 & 19.6 & 23.3 & - \\
Xuño & 2.3 & 0.005 & 2.3 & 1.7 \\
Vixán & 18.0 & 3.4 & 16.4 & - \\
Bodeira & 1.7 & 0.1 & 1.2 & 0.8 \\
\hline
\end{tabular}

\subsubsection{Coastal Lagoons-Louro}

The estimated surface area of the Louro lake is $33.6 \mathrm{ha}$, distributed across three environmental units: open water, macrophytes (especially reed beds, communities of Phragmites australis) and herbaceous formations (Figure 3; Table 3).
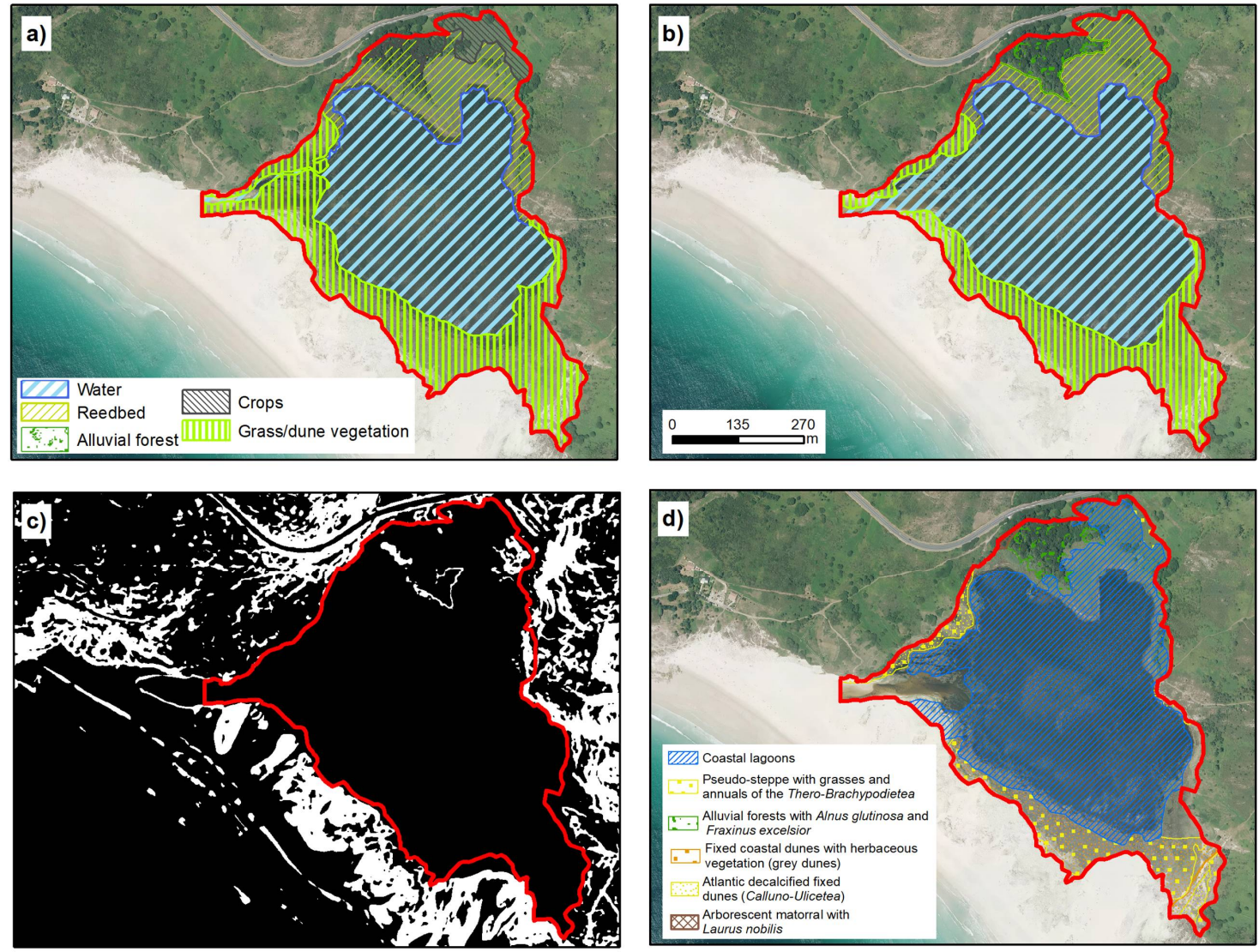

Figure 3. Coastal lagoon of Louro. $(\mathbf{a}, \mathbf{b})$ represent the temporal evolution of environmental units in 1989 and 2017, respectively. (c) shows Topographic Ruggedness Index (TRI) classification, in black, values below mean and in white the values above mean. (d) Official cartography representing the distribution of habitats from Annex I of Habitats Directive. The red line in all cases represent the extent marked for the lagoon by our analysis (IGN [20]; Xunta de Galicia (C).

Open water has a total surface area of 19.6 ha, representing $58.2 \%$ of the lake. This unit has not suffered substantial changes in the last three decades (Figure 3), although large seasonal oscillations occur. The marked seasonal rainfall, with an important water deficit in summer, leads to 
a reduction of $60 \%$ in the area occupied by the sheet of water in the end of summer relative to the maximum during the winter [15].

The second unit is a meadow dominated by grass (Paspalum vaginatum) and to a lesser extent by Scirpus maritimus (association of Scirpetum maritimae) [34]. This plant formation occurred at the front of the lake and occupied an area of 7.9 ha (23.6\%). However, most of this formation was covered by water during periods of maximum water availability (January-April), overlapping seasonally with the open water sector. The reed bed, with presence of Thypha latifolia increased in the peripheral areas, located in the distal and north part of the lake, occupying $14 \%$ of the total surface area.

In the official PDRN cartography, the zone was divided in three main categories. Some $75.3 \%$ of the sector was defined as Coastal lagoon, while $12.8 \%$ was fixed coastal dunes and $11.5 \%$ was defined as Pseudo-steppe with grasses. In this classification, the habitat distribution was closely related to the distribution of plant units (mainly phytosociological units) and with a low weight of lake system functionality. There was also evidence of internal inconsistences relative to the criteria used for the habitat designation.

The main designation error in Louro resides in the inclusion of Pseudo-steppe with grasses and annuals of the Thero-Brachypodietea (habitat 6220), which occupy $12.8 \%$ of the surface area in the official cartography; the presence of these plants is very dubious based on the available information and the habitat characteristics. These areas appear at the front of the lake, in an area that is currently dominated by Paspalum vaginatum, a non-native species, and to a lesser extent by Scirpus maritimus, and most of the species associated with habitat 6220 are not present (see [9]).

The environmental conditions do not correspond to the ecological requirements of the characteristics plant communities of this habitat. This is defined as a xerophyte Mediterranean grassland dominated by vivacious, annual grass that grows on calcareous substrates with temporal hydromorphism [37]. None of these categories appeared at the front part of Louro lake. Moreover, this habitat was not mentioned in any zone of the Natura 2000 network in Galicia, based on data provided by the Spanish Ministry of the Environment $[37,38]$ or the European Environment Agency and data obtained in previous studies in the Galician coast. In view of the foregoing and as this unit is located in the lake basin, it should not appear in a separate category. The same applies to the drainage channel, which cannot be considered an independent unit, because it is one of the characteristic elements of this habitat [39]. The pseudo-steppe habitat with grasses should be included as part of the lagoon.

Another important element in the Louro lake, and which appears in other lakes, is the recovery of habitat 91E0 (Alluvial forests with Alnus glutinosa and Fraxinus excelsior, Alno-Padion, Alnion incanae, Salicion albae), which was almost absent in 1989 and now covers a surface area of 1.4 ha. This is a common pattern in a large portion of rivers and wetlands in Galicia and is related to the abandonment of agricultural land in rural areas and the reduction in agricultural activity $[40,41]$.

\subsubsection{Coastal Lagoons-Vixán}

The space classified as lake in Vixán covered an area of 18 ha. However, it must be emphasized that delimitation of the lake proved difficult in relation to the separation from the coastline. Between the lake and the sea, there is a strip of land of length $300 \mathrm{~m}$ occupied by a transition plain with a drainage channel, associated with a salt marsh dominated by Juncus maritimus, Juncus acutus, and Scirpus maritimus (Figure 4). This category continues at the back of the dune system, which hampers delimitation of the area. The main criteria used for habitat delimitation was the identification of hydrophyte vegetation as a dominant formation.

Regarding the environmental units, most of the area was occupied by reed bed (54.9\%), while open water occupied $18.8 \%$. In addition, an area of salt marsh occurred at the front part (26.3\%).

In relation to the surface area of alluvial forest that appears in the official cartography, its inclusion was ruled out, because the extension was negligible and limited to a few specimens of Alnus glutinosa and Salix atrocinerea that did not constitute a continuous forest. 

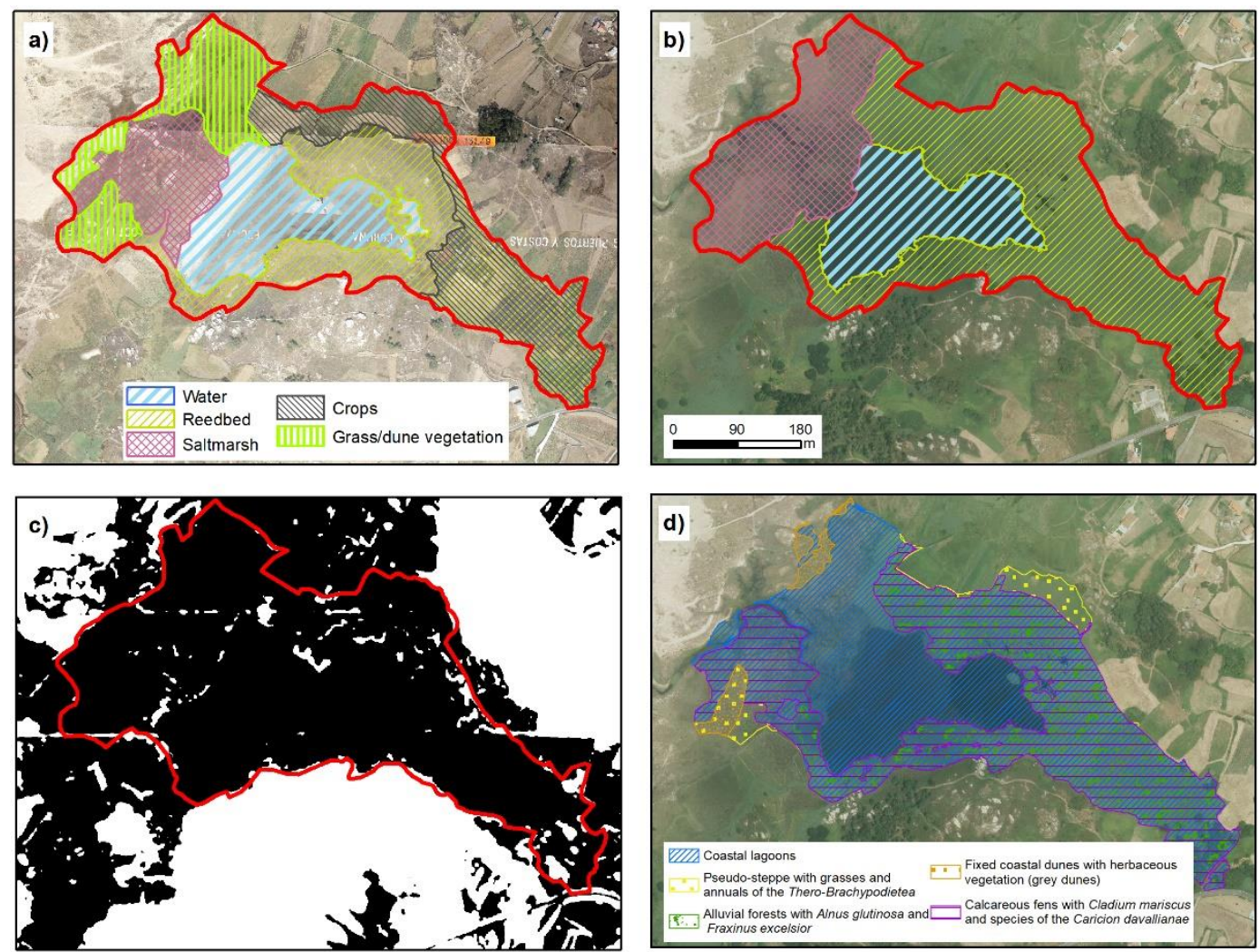

Figure 4. Coastal lagoon of Vixán. $(\mathbf{a}, \mathbf{b})$ represent the temporal evolution of environmental units in 1989 and 2017, respectively. On the lagoon back appear two categories, reedbed and crops, because this part is occupied for reedbeds and the local inhabitants using the zone for their crops. (c) shows TRI classification, in black, values below mean and in white the values above mean. (d) Official cartography representing the distribution of habitats from Annex I of Habitats Directive. The red line in all cases represent the extent marked for the lagoon by our analysis (IGN [20]; Xunta de Galicia (C).

Unlike the proposed classification, PDRN divided the Vixán lake into three main habitats: coastal lagoon (94.7\% of the area), calcareous fens with Cladium mariscus and Caricion davallianae (54.7\%) and alluvial forest (45.7\%). The proportions of each of these habitats indicate an important degree of overlap between units. For instance, the area registered as alluvial forest was simultaneously identified as coastal lagoon and calcareous fens.

Figure 5 shows this habitat overlapping at the back of the lake. In this respect, the alluvial forest was not relevant in Vixán (Figure 4). The disperse trees occurred in the distal zone and occupied a surface area (based on their canopy) of $395 \mathrm{~m}^{2}$, i.e., much smaller than the $76,000 \mathrm{~m}^{2}$ registered in the PDRN. The small area occupied, and their lack of continuity indicated that this unit should be removed and that the zone designated as alluvial forest should be re-designated as reed bed, because the species associated with this habitat predominate in this lake zone.

The habitat designation in the front part of the lake differed from the official cartography. In the PDRN, a zone of calcareous fens (7210) appears in this area. This habitat is associated with water margins, flowing, or standing in hygroturb calcareous soils, with communities dominated by Cladium mariscus. Recent studies [34] have shown that the substrate of the zone is acidic or even very acidic ( $\mathrm{pH} 4-6)$. This finding is incompatible with the term "calcareous" that defines and characterizes this habitat. Habitat 7210 is considered by some authors as mixed habitat, defined by the characteristics of the physical environment (substrate) and the vegetation. Several environmental agencies consider that, although the presence of plant cover with a particular structural characteristic is very important in the habitat definition, this should be developed in a marshy area and on calcareous soils [42,43]. 


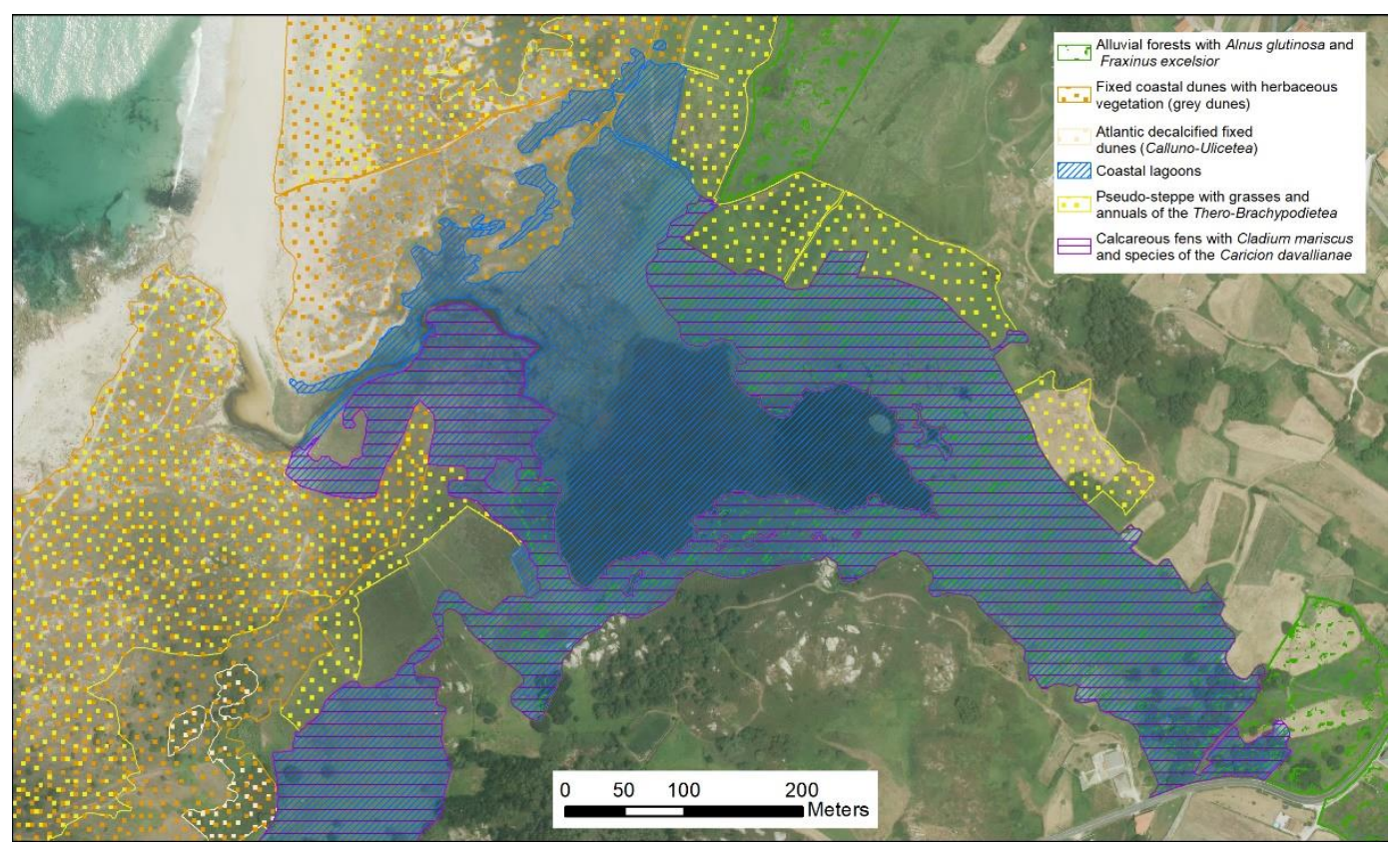

Figure 5. Vixán lagoon with the main habitats defined by Plan Director Rede Natura 2000 (PDRN). Data: Xunta de Galicia (C). Areas with multiple patterns correspond with zones with various main categories.

Furthermore, Cladium mariscus forms a part of a mosaic of fen communities, but the existence of a small number of specimens of this species is not sufficient to justify designation of area as this habitat [43], as occurs in the Vixán lake.

The presence of Cladium mariscus is not in doubt in this area (e.g., [30]), but the existence of habitat 7210 is questioned (e.g., [38,44]), and especially of the large surface area designated in the PDRN. A large part of the area assigned to this habitat (Figure 5) was occupied by different species of Juncus (e.g., Juncus acutus and Juncus maritimus) and Scirpus maritimus, corresponding a typical salt marsh in the NW Iberian Peninsula.

Considering the previously identified criteria and the presence of Cladium mariscus in this zone, detailed analysis must be carried out to establish the presence, distribution, and extension of this species. Nevertheless, considering reports of the presence and distribution of this habitat in Spain, the presence of the species close to the Vixan lake or in the Corrubedo humid complex (LIC ES1110006) seems unlikely [44]. Based on the previous findings, all of the lake front can be considered salt marsh dominated by Scirpus maritimus and several species of reeds, the zone can be included in the Coastal lagoon habitat, as in the case of the reed bed, based on the Commission of the European Communities directrices [9], in which the salt marsh appears as a related habitat included in Coastal lagoons.

Analysis of the temporal changes in the lake shows substantial changes in the distribution of plant communities and the surface area occupied by the sheet of water (Figures 4 and 6). The most important difference is the subdivision of reed bed in plots, which is related to the extraction of Phragmites australis by the local population, for use as livestock bedding. This traditional activity was abandoned at the end of the 1980s, partly as a consequence of the environmental protection of this lake. This led to accumulation of plant biomass, which often drifts into wildfires at the end of summer (Figure 6). The fires lead to substantial degradation of the water quality.

Additionally, clogging of the lake promotes expansion of the reed bed to the detriment of the area of open water [15]. One of the consequences of this expansion is the disappearance of channels and, in general, the area of contact between water and vegetation, a key parameter for the conservation of multiple species of aquatic birds and passerines such as the reed warbler and sedge warbler, 
among other species. Different studies and manuals mention loss of biodiversity in relation to the increase in reed bed density and the reduction in open water [45-49].

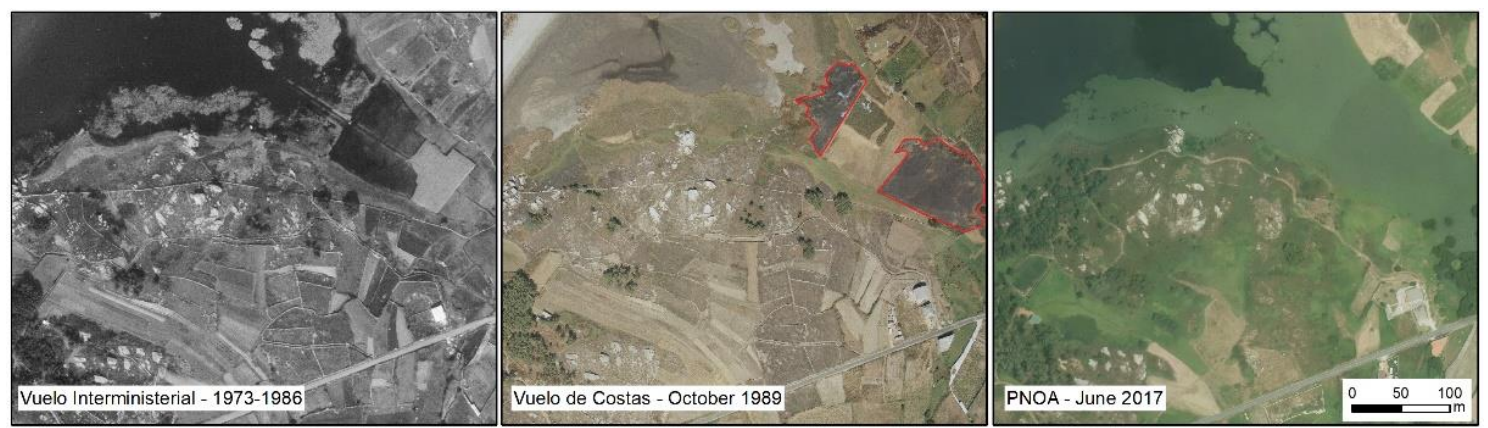

Figure 6. Evolution of Vixan lagoon SE sector. From left to right the images correspond with Interministerial flight (1973-1986); Coastal flight in October 1989 and PNOA image in June 2017. Data: (IGN, [20]). Red polygons in 1989 represents burnt reedbed. The burning in this lagoon part was frequent at the end of summer.

Previous studies of the Vixán lake showed that the numbers of overwintering waterbirds (e.g., waterfowls, common coot, and little grebe) have decreased greatly in the last few decades as consequence of the progressive clogging of the lake and expansion of the reed bed [50,51]. The results of the present study in relation to the water quality, as well the findings of previous studies showed that the water quality is very poor during the summer due to the high organic matter content and presence of reduced forms of $\mathrm{N}\left(\mathrm{NO}_{2}{ }^{-}, \mathrm{NH}_{4}{ }^{+}\right)$, which lead to fish mortality events [34,52]. This is especially important considering that designation of the area as a Site of Community Importance (SCI) was partly related to the protection of birds (declaration of Special Protection Areas for Birds [SPAB]). Some of the values for their protection are missing due to environmental mismanagement.

There are some inconsistencies in the official delimitation of the lakes considered in this study. Thus, while in Vixan the reed bed surface at the back of the lake is included as part of a coastal lagoon habitat, in the case of Louro, a similar zone is identified as an individual unit (Figures 3 and 4).

\subsubsection{Eutrophic Lakes-Xuño}

The total surface area of the Xuño lake is 2.3 ha and hydrophilic vegetation is currently colonizing almost all of the lake. The surface area occupied by open waters was small ( $0.005 \mathrm{ha})$ and decreased by more than half in the study period [15]. The lake basin is occupied by reed bed (77.5\%) in the distal part and by Scirpus maritimus at the front (14.8\%), with the presence of small areas occupied by Thypha latifolia (Figure 7).

The limits of the Xuño lake proposed in this work are almost consistent with those established by the PDRN. Nevertheless, in the PDRN, 99.5\% of the surface area was registered as Coastal lagoon, which appears to be an error. The Xuño lake is located at an elevation of 5 m.a.s.l. and as the channel only acts as a drain, there is no marine influence [15]. This also appear clearly in the analysis of this area, as summarized in Table 2 and Figure 2.

There is also habitat division in this location, which includes coastal lagoon habitat, dune (2130) (0.01 ha) and alluvial forest (91E0) (almost non-existent). Currently these zones are occupied by reed bed, Scirpus maritimus and floating aquatic vegetation (Potamogeton natans, Nymphaea alba). 

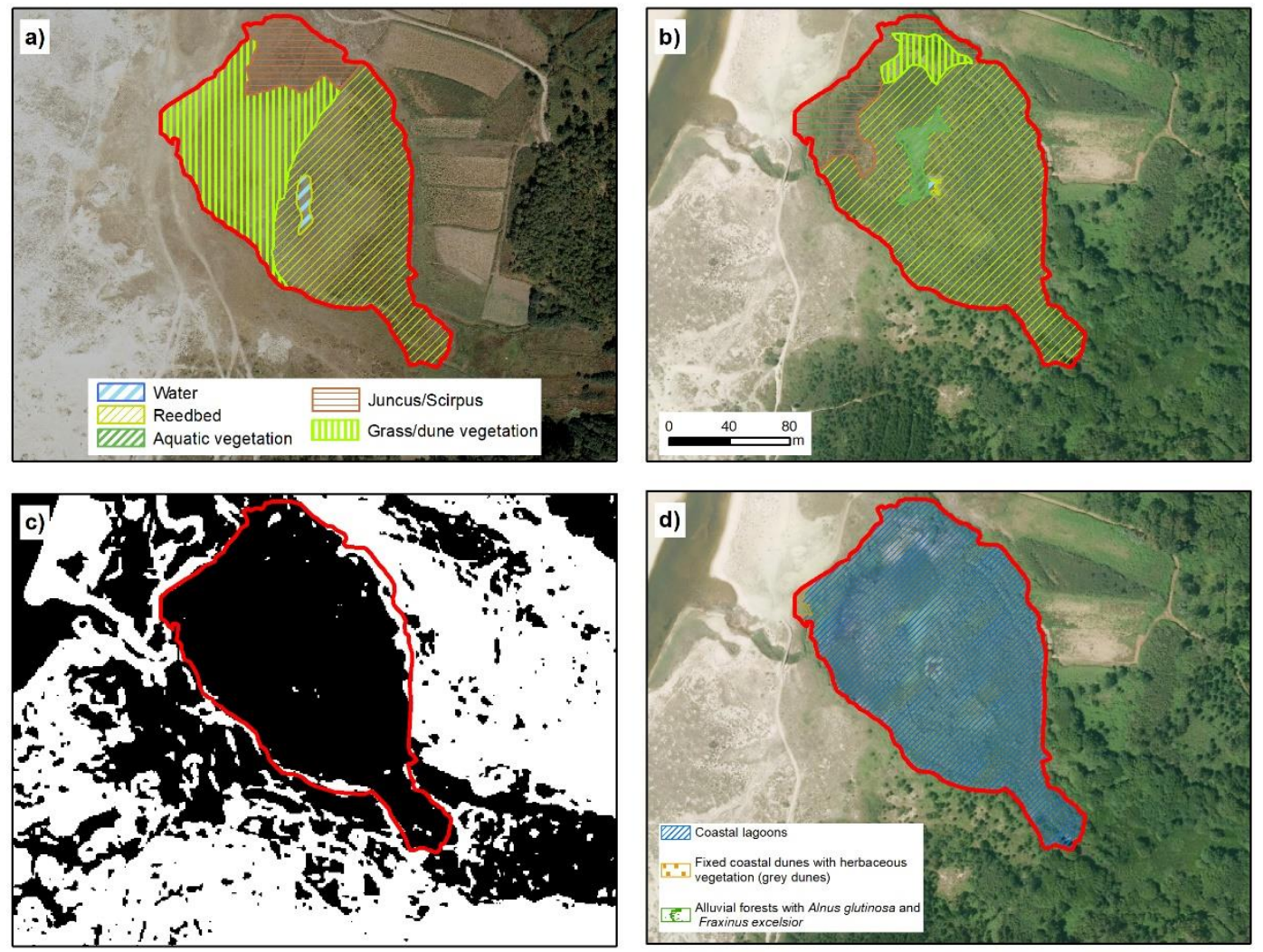

Figure 7. Lake of Xuño. (a,b) represent the temporal evolution of environmental units in 1989 and 2017, respectively. (c) shows TRI classification, in black, values below mean and in white the values above mean. (d) Official cartography representing the distribution of habitats from Annex I of Habitats Directive. The red line in all cases represent the extent marked for the lagoon by our analysis (IGN, [20]; Xunta de Galicia (C).

\subsubsection{Eutrophic Lakes-Bodeira}

The Bodeira lake occupies an area of 1.7 ha (Figure 8), with only $6.2 \%$ of open water. The seasonal variation in Bodeira is more extreme than in the other lakes, as at the end of summer the lake basin is empty of water. The aquatic vegetation and the Phragmites australis occupy 20.7 and $28.8 \%$ of the area, respectively. The increase in the alluvial forest mentioned in other lakes was also observed in Bodeira, where this habitat occupied $44.4 \%$ of the area considered and has undergone a large increase in the last few decades. The recovery of alluvial forest with Alnus glutinosa is the most relevant characteristic of this lake. In the Bodeira area, this type of cover has increased from 0.18 ha (in 1989) to 0.77 ha (in 2017). Outside the lake area, this habitat has increased from 0.53 ha to 6.47 ha of continuous forest.

In the PDRN, the Bodeira lake simultaneously appears as a coastal lagoon and a natural eutrophic lake (Figure 9), even though these habitats are not compatible. Based on the results of water and sediment analysis, this lake should be designated as habitat 3150 (Table 2), which coincides with the information in Ramsar Fact Sheets, in which this lake is defined as a small freshwater coastal lake. As in Xuño, there are also small areas with other main habitats, such as alluvial forest ( $0.38 \mathrm{ha}$ ) and pseudo-steppes $(0.09 \mathrm{ha})$. This adds to the problem of the simultaneous definition as a coastal lagoon and natural eutrophic lake.

Both lakes show important similarities (regarding the water and sedimentary composition) to freshwater lakes separated from the sea (see Section 3.3). The high contents of nutrients ( $\mathrm{N}$ and P) also indicated that the lakes are eutrophic and justify inclusion of the lakes in habitat 3150 [15]. The inclusion in a same zone of coastal lagoons and a natural eutrophic lake (Table 3 and Figure 9) is clearly an error. The characteristics of each habitat in the same water mass and their physiochemical 
parameters cannot be very different, as shown in Table 2. Coastal lagoon occupied a major part of these lakes (Figure 9), and although it is the main habitat, this space cannot be considered a linked natural eutrophic lake.
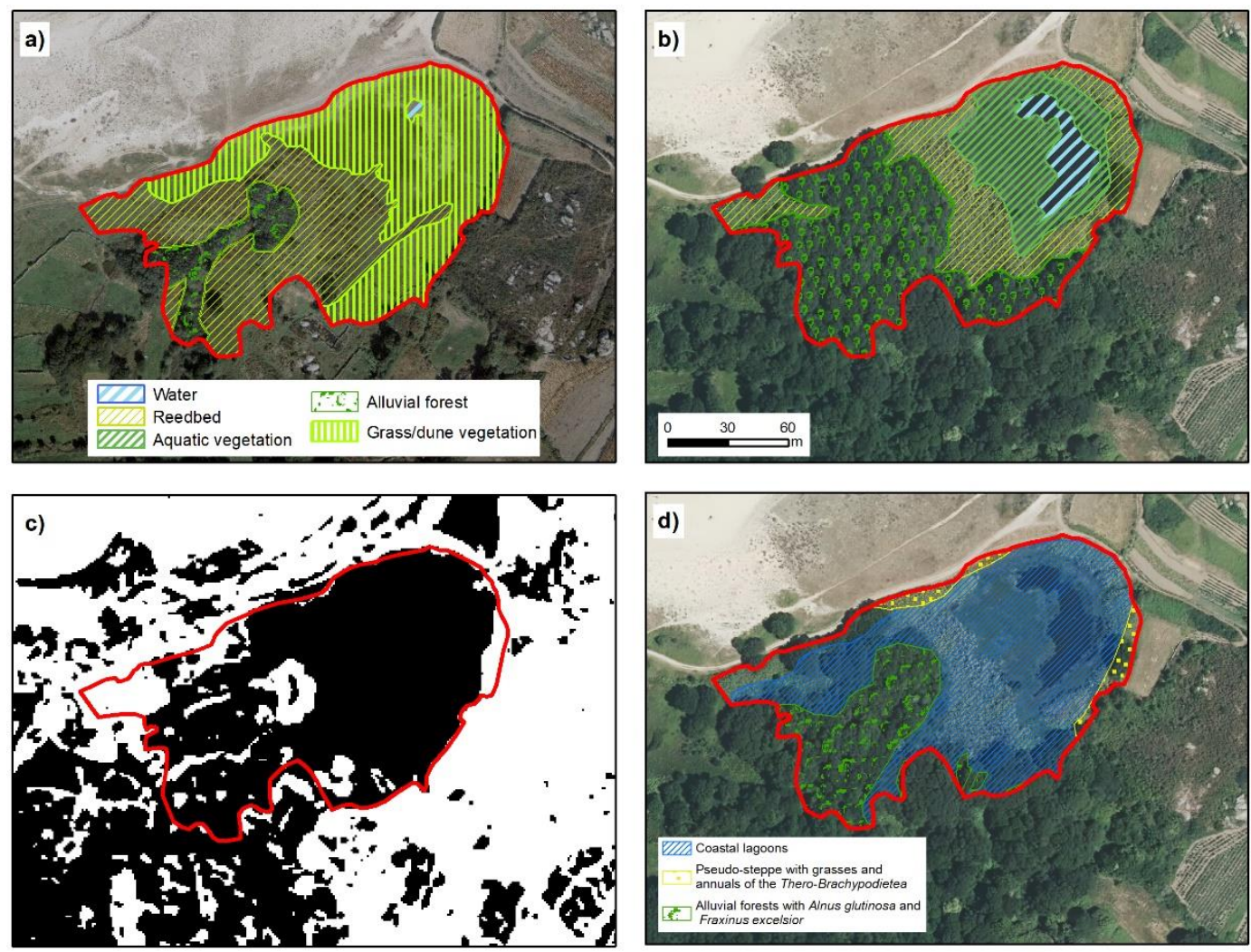

Figure 8. Lake of Bodeira. (a,b) represent the temporal evolution of environmental units in 1989 and 2017, respectively. (c) shows TRI classification, in black, values below mean and in white the values above mean. (d) Official cartography representing the distribution of habitats from Annex I of Habitats Directive. The red line in all cases represent the extent marked for the lagoon by our analysis (IGN, [20]; Xunta de Galicia (C).
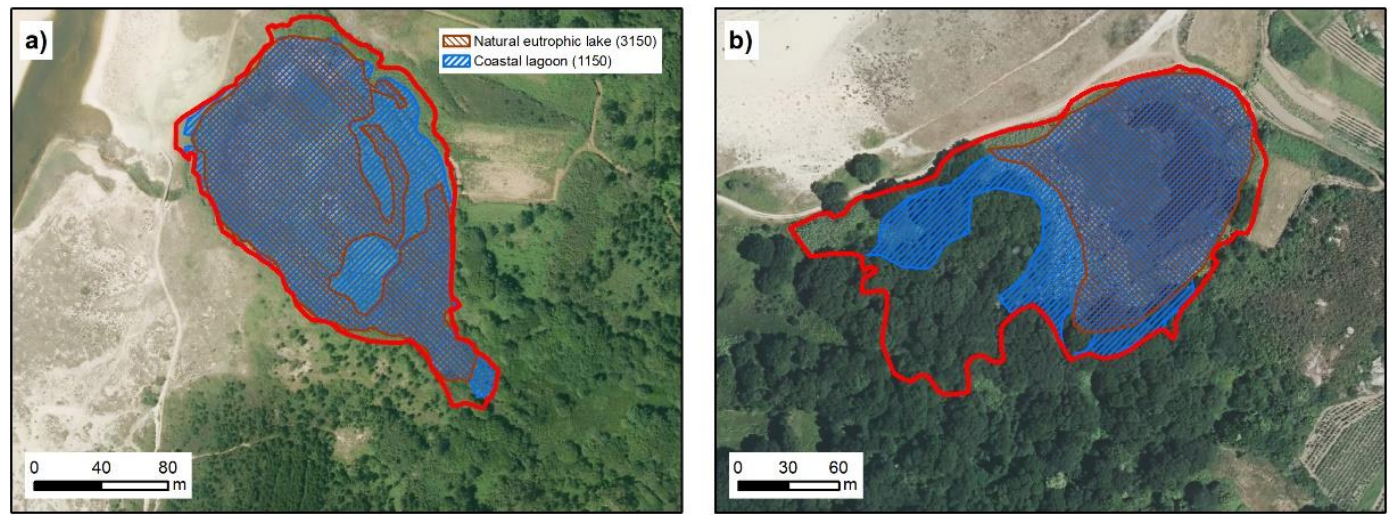

Figure 9. (a) represent lake of Xuño and (b) represent lake of Bodeira. In both cases it shows the surface occupied by coastal lagoon habitat (blue), and natural eutrophic lake habitat (brown). The red line in all cases represent the extent marked for the lagoon by our analysis (IGN [20]; Xunta de Galicia C).

In relation to the habitat division, particularly in relation to the categorization of eutrophic lakes by PDRN (Figures 7 and 8), in the present study it was considered that the lake basin corresponds to a unique habitat and that division in units with a limited spatial representation does not correspond to the functionality of wetlands. Indeed, this division appears to have arisen as the result of erroneous land 
analysis using only botanic and phytosociological criteria. This highlights the need to delimit wetlands and their habitats by using an integrated approach, including botanic, hydrological, sedimentary, and faunistic analysis.

\subsection{Anomalies in Elaboration of the Natura 2000 Network}

The anomalies mentioned in previous section have led to various errors during the development of the Natura 2000 network in Galicia. First, the absence of previous debate among experts in the different areas (botanic, ecology, zoology, geochemistry, etc.) that would have permitted the definition of each habitat to be adapted to the real situations in Galicia. Secondly, the interpretation and identification of habitats to each LIC in Galicia was almost exclusively conducted by botanists. Thus, the fact that the presence of several habitats required not only botanical knowledge (flora and vegetation) but also knowledge about the physical environment (substrate, lithology, soils, etc.) was overlooked.

These errors have led to the current situation whereby the regional authorities must elaborate specific studies for these complex habitats, for which dubious definitions have been made [31]. These studies clearly show errors in designation concerning the presence and extension of the habitats, e.g., the classification of some zones in habitat 2150* (Atlantic decalcified fixed dunes (Calluno-Ulicetea) or in the group 71 habitats (active raised bogs) [29].

\subsection{Developmental Trends}

The general trend in these coastal lake systems is for them to become clogged, through a process that is already well advanced. The process has perhaps been further accelerated in the last 30 years as consequence of abandonment of traditional activities such as the annual extraction of macrophytes (sedges or reed beds). This is clearly observed in the small Xuño and Bodeira lakes, where during the summer most of the area usually occupied by the lakes are now dry: the Bodeira lake generally remains dry between the end of August to October (Figure 10). In order to maintain the quality of these systems, as well as the natural values whereby they can be included in the Natura 2000 network, the application of different management plans, such as dredging the lakes, should be considered. Article 6 of the Habitats Directive established that this type of activity can improve the quality and functionality of these systems. These methods have been applied through the LIFE program [53] in different lakes included in the Natura 2000 network in Spain, Italy, Greece and Portugal. The practice of drainage is addressed in article 17 of the Habitats Directive, which in 2007-2012 highlighted the major threat that eutrophication represents to these lakes in relation to the associated pollution and changes in the water level [53].

In contrast to the changes in open water surfaces, the alluvial forest (91E0) underwent an important increase in the last three decades in Louro, Xuño, and Bodeira, which in some cases exceed 10 times the surface area reported in 1989 (Figure 3, Figure 7, and Figure 8). This change had important effects on the system configuration (Figure 10), simultaneously highlighting the need for an urgent review of the current state of Natura 2000 network spaces, in relation to the presence, delimitation and distribution of habitats [54,55]. The increase in the surface area occupied by alluvial forest is very common in Galician lakes, in both coastal and inland areas, as a consequence of the drastic reduction in agricultural activity in Galicia in the last 50 years [41]. 

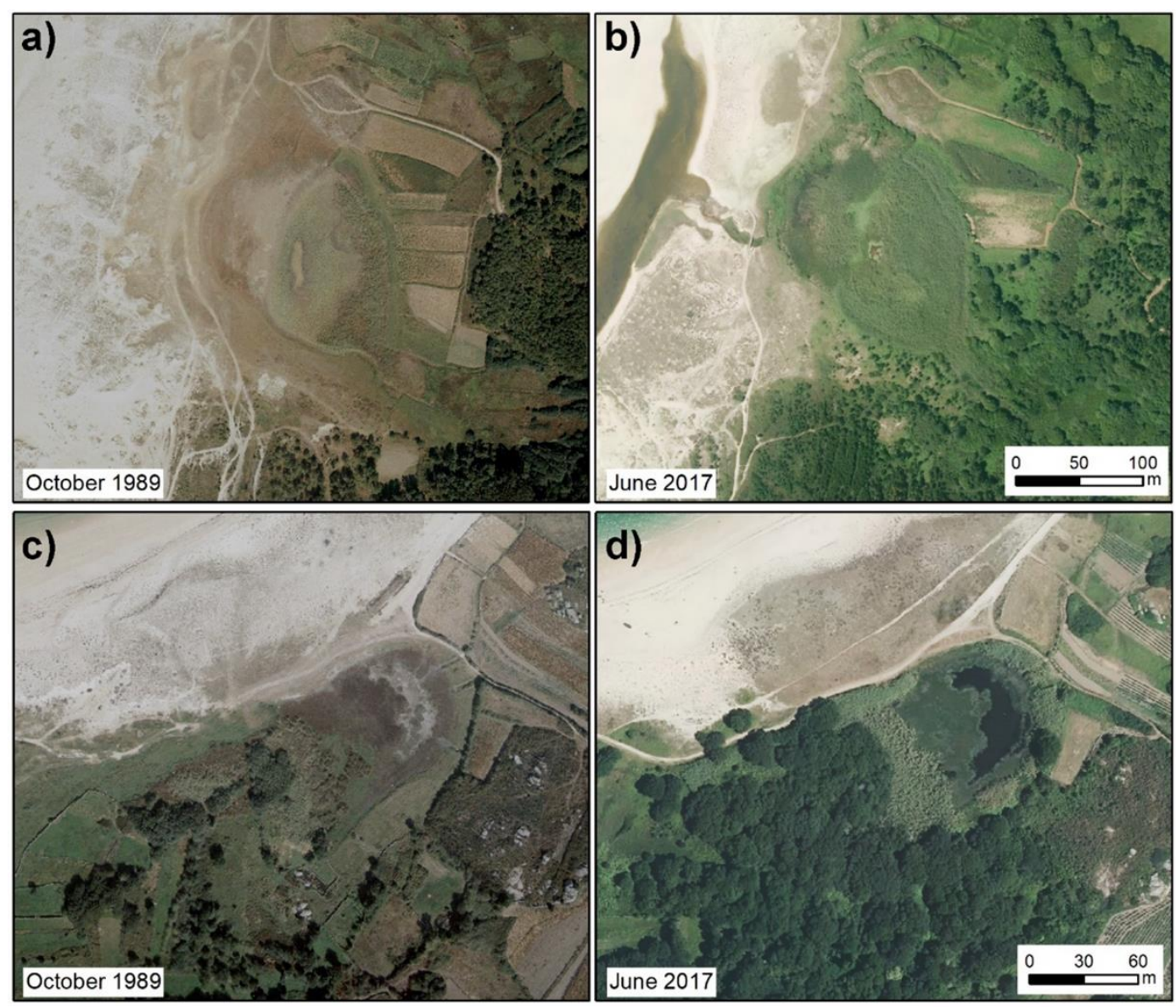

Figure 10. (a,b) represent the evolution of Xuño coastal lake between 1989 (a) and 2017 (b-d) show the evolution of Bodeira coastal lake between 1989 (c) and 2017 (d). Data: (IGN, [20]). An important factor to highlight in these images is the increase of alluvial forest in 2017 in relation to 1989, this habitat rises since 0.53 ha of continuous forest to 6.75 ha.

\subsection{New Technologies in Ecosystem Delimitation}

LiDAR data proved to be valuable for delimiting the habitats in which the edges were associated with variations in relief, enabling up-to-date characterization of the lake surface with an uncertainty of around 4\%, compared to remote sensing techniques, except in the case of the Louro lake. However, lake zones should be defined by taking other data sources into account, because LiDAR analysis may include part of the areas around the lake where there is little variation in relief [56]. This was clear in the Vixán lake where the TRI values of the cropped area were similar to those of the lake surface.

To improve the management of these environments, detailed studies should be conducted to monitor the seasonal and annual variations in the lake systems. Field surveys should be carried out to analyze water and sedimentary parameters. The use of Unmanned Aerial Vehicles (UAVs) could be valuable for quantifying spatial variations and for estimating vegetation growth and other related parameters [57-60].

\section{Conclusions}

Based on the information derived from a study of these lakes, information about the vegetation and the composition of the water and sediments, the following can be concluded:

1. Only two of the lakes (Louro and Vixán) can be considered Coastal lagoons (habitat 1150).

Both Bodeira and Xuño are natural eutrophic lakes (habitats 3150). 
2. The presence, designation and distribution of the habitats defined by PDRN should be revised in depth. Each lake is per se a functional unit and habitat, formed by different environments such as open waters, channels, salt marshes and reedbeds. Classifying each unit as a different habitat contradicts the philosophy of the Habitats Directive and complicates management of the ecosystems involved.

3. The Vixán, Xuño, and Bodeira lakes are characterized by advanced states of eutrophication and poor water quality. Restoration of hydraulic functionality should be investigated further.

4. The expansion of alluvial forest is an example of the rapid evolution of these systems in relation to halting anthropogenic pressure.

5. The delimitation of lakes should be revised by using technologies such as LiDAR and remote sensing.

Author Contributions: Conceptualization, A.P.-A., X.L.O.; methodology, A.G.-P., X.L.O., A.P.-A. and P.F.-S., formal analysis, A.P.-A., A.G.-P., M.S.-S., P.F.-S. and X.L.O.; writing-original draft preparation, A.P.-A., X.L.O. and A.G.-P.; writing-review and editing, A.P.-A., X.L.O., M.S.-S. and A.G.-P. All authors have read and agreed to the published version of the manuscript.

Funding: This work is part of a research project entitled "Monitorización de los procesos biogeoquímicos en las lagunas litorales en relación con su calidad ambiental y respuesta al cambio climático" (Xunta de Galicia, PGIDIT08MDS036000PR), the program for consolidation of competitive research groups (Axudas á consolidación e estruturación de unidades de investigación competitivas do SUG del Plan Galego IDT, Ambiosol Group ref. 2018-PG036), and Cross-Research in Environmental Technologies, CRETUS (Xunta de Galicia GRUP2015/02, ref. 2018-PG100). A.G.-P. is supported by an FPU predoctoral contract by the Spanish government (Ministerio de Educación, Cultura y Deporte). Grant Number: FPU16/03050.

Acknowledgments: This work was supported by CRETUS Institute. A.G.-P. was in receipt of an FPU predoctoral contract with reference FPU16/03050. We would like to thank María Santiso for her assistance with laboratory work and Christine Francis for providing language support.

Conflicts of Interest: Authors declare no conflict of interest.

\section{References}

1. Basset, A.; Elliott, M.; West, R.J.; Wilson, J.G. Estuarine and lagoon biodiversity and their natural goods and services. Estuar. Coast. Shelf Sci. 2013, 132,1-4. [CrossRef]

2. Brito, A.; Newton, A.; Tett, P.; Fernandes, T.F. Sediment and waternutrients and microalgae in a coastal shallow lagoon, Ria Formosa (Portugal): Implications for the Water Framework Directive. J. Environ. Monit. 2010, 12, 318-328. [CrossRef] [PubMed]

3. Kirpotin, S.N.; Berezin, A.; Bazanov, V.; Polishchuk, Y.; Vorobiov, S.; Mironycheva-Tokoreva, N.; Kosykh, N.; Volkova, I.; Dupre, B.; Pokrovsky, O.; et al. Western Siberia wetlands as indicator and regulator of climate change on the global scale. Int. J. Environ. Stud. 2009, 66, 409-421. [CrossRef]

4. Mitsch, W.; Gosselink, J. Wetlands; Van Nostrand Reinhold: New York, NY, USA, 1993.

5. García, G.; Muñoz-Vera, A. Characterization and evolution of the sediments of a Mediterranean coastal lagoon located next to a former mining area. Mar. Pollut. Bull. 2015, 100, 249-263. [CrossRef]

6. Garrido, J.; Pérez-Bilbao, A.; Benetti, C.J. Biodiversity and Conservation of Coastal Lagoons. In Ecosystems Biodiversity; Grillo, O., Venora, G., Eds.; InTech: Vienna, Austria, 2011; pp. 1-28.

7. Casado de Otaola, S.; Montes del Olmo, C. Guía de los Lagos y Humedales de España; Reyero, J.M., Ed.; Reyero Ed: Madrid, Spain, 1995.

8. Gattenlöhner, U.; Hammerl-Resch, M.; Jantschke, S. Restauración de Humedales-Manejo Sostenible de Humedales y Lagos Someros; Global Nature Fund (GNF): Radolfzell, Germany, 2004.

9. Commission of the European Communities Interpretation Manual of European Union Habitats; Office for Official Publications of the European Communities: Luxembourg, 2013.

10. Commission of the European Communities Managing Natura 2000 Sites. The Provisions of Article 6 of the "Habtitas" Directive 92/43/EEC; Office for Official Publications of the European Communities: Luxembourg, 2000; ISBN 9282890481.

11. POLGalicia. Plan. de Ordenación do Litoral de Galicia; Consellaría de Medio Ambiente, Territorio e Infraestruturas: Santiago de Compostela, Spain, 2010. 
12. Perez-Alberti, A.; Gomez-Pazo, A. The Rocky Coasts of Northwest Spain. In The Spanish Coastal Systems; Springer: Cham, Switzerland, 2019; pp. 27-47. ISBN 9783319931692.

13. Evans, D. The Habitats of the European Union Habitats Directive. Biol. Environ. Proc. R. Irish Acad. 2006, 106, 167-173. [CrossRef]

14. Haslett, S.K. Coastal Systems; University of Wales Press: Cardiff, UK, 2016; ISBN 178316901X.

15. Fraga-Santiago, P.; Gómez-Pazo, A.; Pérez-Alberti, A.; Montero, P.; Otero Pérez, X.L. Trends in the Recent Evolution of Coastal Lagoons and Lakes in Galicia (NW Iberian Peninsula). J. Mar. Sci. Eng. 2019, 7, 272. [CrossRef]

16. Bao, R.; Alonso, A.; Delgado, C.; Pagés, J.L.L. Identification of the main driving mechanisms in the evolution of a small coastal wetland (Traba, Galicia, NW Spain) since its origin 5700 cal yr BP. Palaeogeogr. Palaeoclimatol. Palaeoecol. 2007, 247, 296-312. [CrossRef]

17. Sáez, A.; Carballeira, R.; Pueyo, J.J.; Vázquez-Loureiro, D.; Leira, M.; Hernández, A.; Valero-Garcés, B.L.; Bao, R. Formation and evolution of back-barrier perched lakes in rocky coasts: An example of a Holocene system in north-west Spain. Sedimentology 2018, 65, 1891-1917. [CrossRef]

18. González-Villanueva, R.; Pérez-Arlucea, M.; Alejo, I.; Goble, R. Climatic-related factors controlling the sedimentary architecture of a Barrier-Lagoon complex in the context of the Holocene transgression. J. Coast. Res. 2015, 627-631.

19. Carballeira, A.; Devesa, C.; Retuerto, R.; Santillán, E.; Ucieda, F. Bioclimatología de Galicia; Fundación Pedro Barrié de la Maza, Conde de Fenosa: A Coruña, Spain, 1983; ISBN 84-85728-27.

20. IGN Instituto Geográfico Nacional. 2020. Available online: https://www.centrodedescargas.cnig.es/ (accessed on 21 October 2020).

21. Riley, S.J.; DeGloria, S.D.; Elliot, R. A Terrain Ruggedness Index that Qauntifies Topographic Heterogeneity. Intermt. J. Sci. 1999, 5, 23-27.

22. Leventhal, J.S. Carbon-sulfur plots to show diagenetic and epigenetic sulfidation in sediments. Geochim. Cosmochim. Acta 1995, 59, 1207-1211. [CrossRef]

23. Berner, R.A. Burial of organic carbon and pyrite sulfur in the modem ocean: Its geochemical and environmental significance. Amer. J. Sci. 1982, 282, 451-473. [CrossRef]

24. Calvert, S.E.; Karlin, R.E. Relationships between sulphur, organic carbon, and iron in the modern sediments of the Black Sea. Geochim. Cosmochim. Acta 1991, 55, 2483-2490. [CrossRef]

25. Otero Pérez, X.L. Monitorización de los Procesos Biogeoquímicos en las Lagunas Litorales en Relación con su Calidad Ambiental y Respuesta Al Cambio Climático; Xunta de Galicia: Santiago de Compostela, Spain, 2011.

26. Otero, X.L.; Ferreira, T.O.; Huerta-Díaz, M.A.; Partiti, C.S.M.; Souza, V.; Vidal-Torrado, P.; Macías, F. Geochemistry of iron and manganese in soils and sediments of a mangrove system, Island of Pai Matos (Cananeia-SP, Brazil). Geoderma 2009, 148, 318-335. [CrossRef]

27. Evans, D. Building the European Union's Natura 2000 network. Nat. Conserv. 2012, 1, 11-26. [CrossRef]

28. Rincón, V.; Velázquez, J.; Gutiérrez, J.; Sánchez, B.; Hernando, A.; García-Abril, A.; Santamaría, T.; Sánchez-Mata, D. Evaluating European conservation areas and proposal of new zones of conservation under the habitats directive. application to Spanish territories. Sustainability 2019, 11, 398. [CrossRef]

29. Pontevedra-Pombal, X.; Souto, M.; García-Rodeja, E. Identificación, Clasificación e Localización dos Tipos de Hábitats de Turbeiras Correspondentes ao Grupo 71 (Turbeiras Ácidas de Esfagnos) do Anexo I da Directiva 92/43/CEE Presentes en Galicia: Áreas de Ampliación da Rede; Editorial Compostela: Santiago de Compostela, Spain, 2019.

30. IBADER. Os Hábitats de Interese Comunitario en Galicia. Fichas Descritivas. Monografías do IBADER.; Editorial Compostela: Santiago de Compostela, Spain, 2008.

31. Otero, X.L.; Pérez-Alberti, A.; Souto, M. Avaliación da Presenza en Galicia do Hábitat de Interese Comunitario Nat2000 2150* Dunas Fixas Descalcificadas Atlánticas (Calluno-Ulicetea); Editorial Compostela: Santiago de Compostela, Spain, 2018.

32. Evans, D. Interpreting the habitats of Annex I: Past, present and future. Acta Bot. Gall. 2010, 157, $677-686$. [CrossRef]

33. Sumares, D.; Fidélis, T. Natura 2000 and the narrative nature of nature: A case for critical discourse analysis. J. Integr. Environ. Sci. 2011, 8, 53-68. [CrossRef]

34. Fraga-Santiago, P. Evolución Morfodinámica y Geoquímica de Diferentes Sistemas Lacustres del Litoral de Galicia; Universidade de Santiago de Compostela: Santiago de Compostela, Spain, 2020. 
35. De Sousa, R.O.; Vahl, L.C.; Otero, X.L. Química e Mineral do solo. Parte II-Aplicações. Viçosa, MG, Soc. Bras. Ciência do Solo. In Química de Solos Alagados; Socidade Brasileira de Ciência do Solo: Berlin, Germany, 2009; pp. 485-528.

36. Berner, R.A.; Raiswell, R. C/S method for distinguishing freshwater from marine sedimentary rocks. Geology 1984, 12, 365. [CrossRef]

37. Ríos, S.; Salvador, F. 6220 Pastizales xerofíticos mediterráneos de vivaces y anual. In Bases Ecológicas Preliminares Para la Conservación de los Tipos de Hábitat de Interés Comunitario en España; VV.AA., Ed.; Ministerio de Medio Ambiente, y Medio Rural y Marino: Madrid, Spain, 2009; p. 88.

38. Bartolomé, C.; Álvarez, J.; Vaquero, J.; Costa, M.; Casermeiro, M.A.; Giraldo, J.; Zamora, J. Los Tipos de Hábitat de Interés Comunitario de España: Guía Básica; Ministerio de Medio Ambiente, Dirección General para la Biodiversidad: Madrid, Spain, 2005; ISBN 8480146273.

39. Baztan, J.; Chouinard, O.; Jorgensen, B.; Tett, P.; Vanderlinden, J.-P.; Vasseur, L. Coastal Zones: Solutions for the 21st Century; Elsevier: Amsterdam, The Netherlands, 2015; ISBN 0128027592.

40. Corbelle Rico, E.; Crecente Maseda, R. Evolución histórica de la Superficie Agrícola Utilizada en Galicia (1962-2006). Integración de fuentes estadísticas y cartográficas. Econ. Agrar. Recur. Nat. 2011, 9, 183. [CrossRef]

41. Corbelle Rico, E.; Crecente Maseda, R. Urbanización, forestación y abandono. Cambios recientes en el paisaje de Galicia, 1985-2005. Rev. Galega Econ. 2014, 23, 35-52.

42. REDIAM. Áreas Pantanosas Calcáreas con Cladium Mariscus y Especies de Caricion Davallianae (Turberas Calcáreas del Cladium Mariscus y con Especies del Caricion Davallianae); Tragsa: Madrid, Spain, 2020.

43. The European Environment Agency. Calcareous Fens with Cladium mariscus and Species of the Caricion Devallianae; The European Environment Agency: Copenhagen, Danmark, 2020.

44. García Rodeja, E.; Fraga Vila, M.I. Bases ecológicas Prelim. para la Conserv. Los Tipos Hábitat Interés Comunitario en España. In 7210 Áreas Pantanosas Calcáreas con Cladium mariscus y Especies de Caricion Davallianae $\left(^{*}\right)$; VV.AA., Ed.; Tragsa: Madrid, Spain, 2009; p. 61.

45. Burgess, N.; Ward, D.; Hobbs, R.; Bellamy, D. Reedbeds, fens and acid bogs. In Managing Habitats for Conservation; Cambridge University Press: Cambridge, UK, 1995; pp. 149-196.

46. Burgess, N.D.; Evans, C.E. The Management of Reedbeds for Birds; RSPB: Bedfordshire, UK, 1989.

47. Hawke, C.J.; José, P.V. English Nat. In Reedbed Management for Commercial and Wildlife Interests; RSPB: Bedfordshire, UK, 1996.

48. Poulin, B.; Lefebvre, G.; Mauchamp, A. Habitat requirements of passerines and reedbed management in southern France. Biol. Conserv. 2002, 107, 315-325. [CrossRef]

49. Trnka, A.; Peterková, V.; Prokop, P.; Batáry, P. Management of reedbeds: Mosaic reed cutting does not affect prey abundance and nest predation rate of reed passerine birds. Wetl. Ecol. Manag. 2014, 22, 227-234. [CrossRef]

50. Souza, J.A.; Lorenzo, M. Fluctuaciones poblacionales, importancia de las localidades y factores que influyen en los patos y fochas invernantes en Galicia. In Proceedings of the Actas do Primeiro Congreso de Ornitoloxía de Galicia; Universidade de Santiago de Compostela, Ed.; Universidade de Santiago de Compostela: Santiago de Compostela, Spain, 1991; pp. 35-67.

51. Vilas, F.; Miralles, A.A.; Ramos, A.; Sopeña, A.; Rey, L.; Nombela, M.A. El complejo de playa-lagoon de Corrubedo y los submedios característicos. Galicia, NW. España. Acta Geológica Hispánica 1986, 21-22, $233-243$.

52. Otero, X.L.; Macías, F. Spatial and seasonal variation in heavy metals in interstitial water of salt marsh soils. Environ. Pollut. 2002, 120, 183-190. [CrossRef]

53. Silva, J.; Toland, J.; Eldrifge, J.; Potter, J.; Jones, S.; Nottingham, S.; Severon, M.; Geater, M.; Jones, W.; Martínez, E. LIFE Nature LIFE and Coastal Habitats; Merciol, J.-C., Ed.; Publications Office of the European Union: Luxembourg, 2017; ISBN 9789279642098.

54. Kovac, M.; Hladnik, D.; Kutnar, L. Biodiversity in (the Natura 2000) forest habitats is not static: Its conservation calls for an active management approach. J. Nat. Conserv. 2018, 43, 250-260. [CrossRef]

55. Vanden Borre, J.; Paelinckx, D.; Mücher, C.A.; Kooistra, L.; Haest, B.; De Blust, G.; Schmidt, A.M. Integrating remote sensing in Natura 2000 habitat monitoring: Prospects on the way forward. J. Nat. Conserv. 2011, 19, 116-125. [CrossRef]

56. Bässler, C.; Stadler, J.; Müller, J.; Förster, B.; Göttlein, A.; Brandl, R. LiDAR as a rapid tool to predict forest habitat types in Natura 2000 networks. Biodivers. Conserv. 2011, 20, 465-481. [CrossRef] 
57. Appeaning Addo, K.; Jayson-Quashigah, P.N.; Codjoe, S.N.A.; Martey, F. Drone as a tool for coastal flood monitoring in the Volta Delta, Ghana. Geoenviron. Disasters 2018, 5. [CrossRef]

58. Green, D.R.; Hagon, J.J.; Gómez, C.; Gregory, B.J. Using Low-Cost UAVs for Environmental Monitoring, Mapping, and Modelling: Examples From the Coastal Zone; Academic Press: Cambridge, MA, USA, 2019; ISBN 9780128104736.

59. Long, N.; Millescamps, B.; Guillot, B.; Pouget, F.; Bertin, X. Monitoring the topography of a dynamic tidal inlet using UAV imagery. Remote Sens. 2016, 8, 387. [CrossRef]

60. Scarelli, F.M.; Sistilli, F.; Fabbri, S.; Cantelli, L.; Barboza, E.G.; Gabbianelli, G. Seasonal dune and beach monitoring using photogrammetry from UAV surveys to apply in the ICZM on the Ravenna coast (Emilia-Romagna, Italy). Remote Sens. Appl. Soc. Environ. 2017, 7, 27-39. [CrossRef]

Publisher's Note: MDPI stays neutral with regard to jurisdictional claims in published maps and institutional affiliations.

(C) 2020 by the authors. Licensee MDPI, Basel, Switzerland. This article is an open access article distributed under the terms and conditions of the Creative Commons Attribution (CC BY) license (http://creativecommons.org/licenses/by/4.0/). 